\title{
Sakubitril/valsartan'ın diğer kalp yetersizliği tedavilerine göre mortalite yararı ne kadar farklı?
}

\author{
Dr. Mehmet Arslan, (D) Dr. Hakkı Kaya \\ Çanakkale Onsekiz Mart Üniversitesi Tıp Fakültesi, Kardiyoloji Anabilim Dalı, Çanakkale
}

Bugüne kadar kalp yetersizliğinde (KY) mortaliteyi azalttığ1 gösterilen ilaçlar; anjiyotensin dönüştürücü enzim inhibitörleri (ACEI), anjiyotensin reseptör blokerleri (ARB), beta-blokerler ve mineralokortikoid reseptör antagonistleri (MRA), ivabradin ve anjiyotensin neprilisin reseptör inhibitörü (ARNI) olan sakubitril/valsartandır.

\section{Anjiyotensin dönüştürücü enzim inhibitörleri}

Anjiyotensin dönüştürücü enzim inhibitörleri, asemptomatik sol ventrikül disfonksiyonundan (SVEF $\leq \% 40)^{[1]}$ ileri evre KY' ye ${ }^{[2-5]}$ kadar geniş yelpazedeki hasta gruplarında sağ kalımı artırmaktadır. ACEI enarapril ile ciddi KY bulunan NYHA IV olgularda yapılan randomize kontrollü CONSENSUS (Cooperative North Scandinavian Enalapril Survival Study ${ }^{[6]}$ çalışmasında günlük 40 mg'a kadar çıkılan enalapril uygulaması plasebo ile karşılaştırıldığında mortalitede 6 ayda $\% 40(\mathrm{p}=0.002)$ ve 1 yilda $\% 31 \quad(\mathrm{p}=0.001)$ azalma sağladıgı görülmüştür. Çalışma sonunda mortalite için toplam göreceli risk azalması (RRR) \%27 $(\mathrm{p}=0.003$ ) olarak bulunmuştur. SOLVD (Studies of Left Ventricular Disfunction) $)^{[7]}$ çalışmasında NYHA sinıf II-III ve SVEF $\leq \% 35$ (ortalama \%25) olan hastalar ortalama 41.4 ay takip edilip enalapril ile plasebo karşılaştırılmış ve mortalitede \%16'lık (RR 0.84; \%95 CI $0.74-0.95 ; \mathrm{p}=0.0036$ ) azalma izlenmiştir. Tamamı LVEF $\leq \% 35$, LVEF<\%40 veya klinik KY mevcut olguları içeren SOLVD tedavi ve önleme çalışmaları, SAVE (Survival and Ventricular Enlargement), AIRE (Acute Infarction Ramipril Efficacy), ve TRACE (Trandolapril in Patients with Reduced Left Ventricular Ejection Fraction) çalışmalarının 12,763 hastalık meta-analizinde plesebo ile karşılaştırıldığında mortalitede \%20 azalma (odds ratio [OR] 0.80,\%95 CI $0.74-0.87)$ izlenmiştir. $^{[8]}$

\section{Anjiyotensin reseptör blokerleri}

Genel olarak anjiyotensin reseptör blokerleri, ACEI'yi tolere edemeyen hastalara önerilmektedirler. ACEİ renin angiotensin sistem blokeri olarak halen ilk tercih edilen ilaç grubudur. ${ }^{[9]}$ ARB'lerin KY'de rolü ilk olarak valsartan ile yapılan Val-HeFT (Valsartan Heart Failure Trial) $^{[10]}$ ile ortaya konulmuştur. Fakat olumlu katkısı mortaliteden (RR 1.02; \%95 CI 0.88-1.18; $\mathrm{p}=0.80$ ) ziyade hastane yatışlarında gözlenmiştir. Kandesartan ile yapılan CHARMadded (Candesartan in Heart failure Assessment of Reduction in Mortality and Morbidity-Added $)^{[11]}$ çalışmasında LVEF $\leq \% 40$ olan 2.548 NYHA class II-IV olgu ramdomize edilmiş ve mortalitede $\% 16$ (UHR 0.84; \%95 CI 0.72-0.98; p=0.029) oranında azalma gözlenmiştir.

\section{Beta-Blokerler}

ACEİ'ne kıyasla BB ile daha fazla randomize kontrollü çalışma yapılmıştır. Bisoprolol ile yapılan CIBIS II (Cardiac Insufficiency Bisoprolol Study II) (HR 0.66; \%95 CI 0.51-0.81; p<0.0001), karvedilol ile yapilan COPERNICUS (Carvedilol Prospective Randomized Cumulative Survival) (RR 0.65; \%95 CI $0.52-0.81 ; \mathrm{p}=0.00013$ ), CAPRICORN (Effect of carvedilol on outcome after myocardial infarction in patients with left-ventricular dysfunction) (HR 0.92, CI $0.80-1.07, \mathrm{p}=0.296$ ), metoprolol suksinat için yapılan MERIT HF (Metoprolol CR/XL Randomized Intervention Trial in Congestive Heart Failure) (RR 0.34; \%95 CI 0.19-0.47; p=0.00009) çalışmaları ile orta-şiddetli semptomatik KY olan 10000'nin üzerinde hasta beta-bloker (bisoprolol, karvedilol ve metoprolol suksinat) ve plaseboya randomize edilmiştir. $\mathrm{Bu}$ çalışmaların sonucunda beta-bloker tedavisinin tüm nedenlere bağlı 1 yıllık mortaliteyi yaklaşık \%34 azalttığg 1 gösterilmiştir. ${ }^{[12-16]}$ Düşük ve korunmuş EF'li 
Tablo 1. DEF-KY'de ilaç tedavilerinin mortalite üzerine etkileri

\begin{tabular}{lccc}
\hline & $\begin{array}{c}\text { Tüm nedenlere bağlı } \\
\text { mortalitede göreceli } \\
\text { risk azalması (RRR) }\end{array}$ & $\begin{array}{c}\text { Tedavi edilmesi gereken } \\
\text { hasta sayısı } \\
\text { (NNT) - süresi }\end{array}$ & $\begin{array}{c}\text { Tedavi edilmesi gereken } \\
\text { hasta sayısı (NNT) - } \\
12 \text { aya standardize }\end{array}$ \\
\hline ACEl/ARB & $\% 17$ & $22-42$ ay & 77 \\
$\beta$-Blocker & $\% 34$ & $28-12$ ay & 28 \\
MRA & $\% 30$ & $9-24$ ay & 18 \\
İvabradin & $\% 17$ & $50-23$ ay & 96 \\
ARNI* $^{*}$ & $\% 16$ & $\mathbf{3 6 - 2 7}$ ay & $\mathbf{8 0}$ \\
\hline
\end{tabular}

*: Diğer ilaçlarla sağlanan mortalite risk azalması plaseboya karşı elde edilmişken, ARNI ile enalaprile karşı elde edilmiştir.

ileri yaş (ortalama yaş 76) KY olgularında yapılan SENIORS (Study of Effects of Nebivolol Intervention on Outcomes and Rehospitalization in Seniors With Heart Failure) çalışması da nebivolol'ün benzer yararlar sağladığını göstermiş. Plasebo ile karşılaştırıldı ğında nebivolol birincil sonlanım noktası olarak kabul edilen ölüm veya kardiyovaskuler nedenlerle hastane yatışta \%14 azalma [hazard ratio (HR) 0.86 , \%95 CI 0.74-0.99; $\mathrm{p}=0.039$ ] sağlamıştır. ${ }^{[17]}$

\section{Minerolokortikoid reseptör antagonistleri}

Kronik KY'de sağkalımı arttırdığ 1 kanıtlanan bir başka ilaç grubu aldosteron antagonistleridir. RALES (The effect of spironolactone on morbidity and mortality in patients with severe heart failure $)^{[18]}$ çalışmasında ACEI, diüretik ve digoksin kullanan sol ventrikül EF $<\% 35$ olan NYHA III-IV KY hastalar 25 mg spiranolakton ve plaseboya randomize edilmiştir. ACEİ tedavisine ilave verilen Spironolaktonun mortalite riskini $\% 30$ oranında azalttığı gösterilmiştir. EPHESUS (Eplerenone, a selective aldosterone blocker, in patients with left ventricular dysfunction after myocardial infarction) ${ }^{[19]}$ çalışmasında ise akut miyokart infarktüsünün 3-14. günlerinde sol ventrikül ejeksiyon fraksiyonu $<\% 40$ olan hastalar ACEI, beta-bloker, düretik tedaviye ilave eplerenon ve plaseboya randomize edilmiştir. Mortalite riskini \%15 oranında azalttı̆̆ 1 gösterilmiştir. EMPHASIS HF (Eplerenone in Mild Patients Hospitalization and Survival Study in Heart Failure $)^{[20]}$ çalışmasında ise NYHA II olgularda eplerenonun 21 aylık takipte mortaliteyi \%24 (HR 0.76 (\%95 CI 0.62 to $0.93, \mathrm{p}=0.008$ ) oranında azalttığı gösterilmiş. Bu çalışmayla birlikte MRA'ların mortalite yararı NYHA II KY olgularda da gösterilmiş ve endikasyonları genişlemiştir.

\section{İvabradin}

İvabradin sinus nodunda If kanallarını bloke ederek sinüs ritmindeki hastalarda kalp hızının azal- tılmasını sağlar. ${ }^{[21]}$ Daha önce yapılan çalışmalarda kalp hızı artışı ile kardiyovasküler ve total mortalite arasında önemli ilişki saptanmıştır. ${ }^{[22,23]}$ İvabradinle yapılan SHIFT çalışmasında sinüs ritminde, kalp hızı $>70$ vuru/dk, SVEF $\leq 35$ olan NYHA II-IV 6558 olgu mevcut KY tedavisine (\%90'1 beta-bloker, \%79'u ACEI, \%14'ü ARB kullanmakta) eklenen ivabradin veya placebo stratejileri ortalama 23 aylık takiple karşılaştırılmıştır. Birincil sonlanım noktası olan KV ölüm ve KY nedeniyle hastane yatışında \%18 azalma bildirilmiştir (HR, 0.82, \%95 CI 0.75-0.9, p<0.0001). Fakat son noktadaki bu etkinlik özellikle KY nedeniyle hospitalizasyonda \%26 azalma ile ilişkili bulunmuş (HR, 0.74, \%95 CI 0.66-0.83, p<0.0001) tek başına kardiyovasküler nedenli ölüm ya da tek başına tüm nedenlere bağlı ölüm de azalma ise anlamlı düzeyde bulunmamıştır. ${ }^{[24]}$ İvabradinin KY tedavisinde kullanımı başvurusu sırasında Avrupa İlaç Ajansının (EMEA) isteği üzerine yapılan SHIFT çalışması verilerine dayalı analizlerde ivabradinin kalp hızı $\geq 75$ vuru/dk ve $<75$ vuru/dk hasta grubunda karşılaştırılmış ve kalp hızı $\geq 75$ vuru/dk olan KY olgularında tüm nedenli ölümlerde \%17 (HR 0.83, \%95 CI 0.72-0.96, p=0.0109) nisbi risk azalması sağladı̆̆ ${ }_{1}$ gösterilmiştir. ${ }^{[25]}$

\section{Sakubitril/valsartan}

PARADIGM-HF (Prospective comparison of ARNI with ACEI to Determine Impact on Global Mortality and morbidity in Heart Failure $)^{[26]}$ çalışmasında, düşük EF KY hastaları optimal tedaviye ilave olarak LCZ696 ve enalaprile randomize edilmiştir. Çalışmaya fonksiyonel kapasitesi NYHA II/ III/IV ve EF $\leq \% 40$ olan KY hastaları dahil edilmiştir. Çalışmada LCZ696 grubundaki hastalarda belirgin yarar görülmesi nedeniyle erken sonlandırılmıştır. Ortalama 27 aylık takipte LCZ696 grubunda tüm nedenli ölümlerde \%16 (HR 0.84; \%95 CI 0.76-0.93) azalma saptanmıştır. 


\section{KY'de farmakolojik tedavilerin sağladığı mortalite yararının kıyaslaması}

Kalp yetersizliğinde standart farmakolojik tedaviler ile elde edilen mortalite yararları Tablo 1'de özetlenmiştir. ${ }^{[27]}$ Tüm nedenlere bağlı mortalitede ACEİ/ ARB \%17, beta-blokerler \%34, MRA'lar \%30, ivabradin \%17'lik bir mortalite düşüşü sağlanmaktadır. Belirtilen bu mortalite yararlarının elde edildiği çalışmaların hepsinde etkileri araştırılan ilaçların plasebo ile karşılaştırıldığı ve bu mortalite yararlarının plaseboya karşı elde edildiği, ARNI'nin sağladığ $1 \% 16$ 'lık mortalite faydasının ise plaseboya karşı değil, KY ilk basamak tedavisi olan ACEİ ile karşılaştırılarak gösterilmiş olduğu göz önünde bulundurulmalıdır. $\mathrm{Bu}$ da ARNI'nin ACEI ile elde edilen \%17'lik mortalite azalması üzerine ilave \%16'lk mortalite azalması sağladığı anlamına gelmektedir.

\section{Kaynaklar}

1. SOLVD Investigators, Yusuf S, Pitt B, Davis CE, Hood WB Jr, Cohn JN. Effect of enalapril on mortality and the development of heart failure in asymptomatic patients with reduced left ventricular ejection fractions [published correction appears in N Engl J Med 1992 Dec 10;327(24):1768]. N Engl J Med 1992;327:685-91.

2. Cohn JN, Johnson G, Ziesche S, Cobb F, Francis G, Tristani F, et al. A comparison of enalapril with hydralazine-isosorbide dinitrate in the treatment of chronic congestive heart failure. $\mathrm{N}$ Engl $\mathrm{J}$ Med 1991;325:303-10.

3. CONSENSUS Trial Study Group. Effects of enalapril on mortality in severe congestive heart failure. Results of the Cooperative North Scandinavian Enalapril Survival Study (CONSENSUS). N Engl J Med 1987;316:1429-35.

4. SOLVD Investigators, Yusuf S, Pitt B, Davis CE, Hood WB, Cohn $\mathrm{JN}$. Effect of enalapril on survival in patients with reduced left ventricular ejection fractions and congestive heart failure. N Engl J Med 1991;325:293-302.

5. Flather MD, Yusuf S, Køber L, Pfeffer M, Hall A, Murray G, et al. Long-term ACE-inhibitor therapy in patients with heart failure or left-ventricular dysfunction: a systematic overview of data from individual patients. ACE-Inhibitor Myocardial Infarction Collaborative Group. Lancet 2000;355:1575-81.

6. CONSENSUS Trial Study Group. Effects of enalapril on mortality in severe congestive heart failure. Results of the Cooperative North Scandinavian Enalapril Survival Study (CONSENSUS). N Engl J Med 1987;316:1429-35.

7. SOLVD Investigators, Yusuf S, Pitt B, Davis CE, Hood WB, Cohn $\mathrm{JN}$. Effect of enalapril on survival in patients with reduced left ventricular ejection fractions and congestive heart failure. N Engl J Med 1991;325:293-302.

8. Flather MD, Yusuf S, Køber L, Pfeffer M, Hall A, Murray G, et al. Long-term ACE-inhibitor therapy in patients with heart failure or left-ventricular dysfunction: a systematic overview of data from individual patients. ACE-Inhibitor Myocardial Infarction Collaborative Group. Lancet 2000;355:1575-81.

9. Maggioni AP, Anand I, Gottlieb SO, Latini R, Tognoni G, Cohn JNet al. Effects of valsartan on morbidity and mortality in patients with heart failure not receiving angiotensin-converting enzyme inhibitors. J Am Coll Cardiol 2002;40:1414-21.

10. Cohn JN, Tognoni G; Valsartan Heart Failure Trial Investigators. A randomized trial of the angiotensin-receptor blocker valsartan in chronic heart failure. N Engl J Med 2001;345:1667-75.

11. McMurray JJ, Ostergren J, Swedberg K, Granger CB, Held P, Mic- helson EL, et al. Effects of candesartan in patients with chronic heart failure and reduced left-ventricular systolic function taking angiotensin-converting-enzyme inhibitors: the CHARM-Added trial. Lancet 2003;362:767-71.

12. CIBIS-II Writers. The Cardiac Insufficiency Bisoprolol Study II (CIBIS-II): a randomised trial. Lancet 1999;353:9-13.

13. Packer M, Fowler MB, Roecker EB, Coats AJ, Katus HA, Krum $\mathrm{H}$, et al. Effect of carvedilol on the morbidity of patients with severe chronic heart failure: results of the carvedilol prospective randomized cumulative survival (COPERNICUS) study. Circulation 2002;106:2194-9.

14. Dargie HJ. Effect of carvedilol on outcome after myocardial infarction in patients with left-ventricular dysfunction: the CAPRICORN randomised trial. Lancet 2001;357:1385-90.

15. Effect of metoprolol $\mathrm{CR} / \mathrm{XL}$ in chronic heart failure: Metoprolol CR/XL Randomised Intervention Trial in Congestive Heart Failure (MERIT-HF). Lancet 1999;353:2001-7.

16. Hjalmarson A, Goldstein S, Fagerberg B, Wedel H, Waagstein F, Kjekshus J, et al. Effects of controlled-release metoprolol on total mortality, hospitalizations, and well-being in patients with heart failure: the Metoprolol CR/XL Randomized Intervention Trial in congestive heart failure (MERIT-HF). MERIT-HF Study Group. JAM 2000;283:1295-302.

17. Flather MD, Shibata MC, Coats AJ, Van Veldhuisen DJ, Parkhomenko A, Borbola J, et al. Randomized trial to determine the effect of nebivolol on mortality and cardiovascular hospital admission in elderly patients with heart failure (SENIORS). Eur Heart J 2005;26:215-25.

18. Pitt B, Zannad F, Remme WJ, Cody R, Castaigne A, Perez A, et al. The effect of spironolactone on morbidity and mortality in patients with severe heart failure. Randomized Aldactone Evaluation Study Investigators. N Engl J Med 1999;341:709-17.

19. Pitt B, Remme W, Zannad F, Neaton J, Martinez F, Roniker B, et al. Eplerenone, a selective aldosterone blocker, in patients with left ventricular dysfunction after myocardial infarction. $\mathrm{N}$ Engl $\mathrm{J}$ Med 2003;348:1309-21.

20. Zannad F, McMurray JJ, Krum H, van Veldhuisen DJ, Swedberg K, Shi $\mathrm{H}$, et al. Eplerenone in patients with systolic heart failure and mild symptoms. N Engl J Med 2011;364:11-21.

21. McMurray JJ, Adamopoulos S, Anker SD, Auricchio A, Böhm M, Dickstein K, et al. ESC Guidelines for the diagnosis and treatment of acute and chronic heart failure 2012: The Task Force for the Diagnosis and Treatment of Acute and Chronic Heart Failure 2012 of the European Society of Cardiology. Developed in collaboration with the Heart Failure Association (HFA) of the ESC. Eur Heart J 2012;33:1787-847.

22. Cooney MT, Vartiainen E, Laatikainen T, Juolevi A, Dudina A, Graham IM. Elevated resting heart rate is an independent risk factor for cardiovascular disease in healthy men and women. Am Heart $\mathrm{J}$ 2010;159:612-9.e3.

23. Kannel WB, Kannel C, Paffenbarger RS Jr, Cupples LA. Heart rate and cardiovascular mortality: the Framingham Study. Am Heart J 1987;113:1489-94.

24. Swedberg K, Komajda M, Böhm M, Borer JS, Ford I, Dubost-Brama A, et al. Ivabradine and outcomes in chronic heart failure (SHIFT): a randomised placebo-controlled study. Lancet 2010;376:875-85.

25. Böhm M, Borer J, Ford I, Gonzalez-Juanatey JR, Komajda M, LopezSendon J, et al. Heart rate at baseline influences the effect of ivabradine on cardiovascular outcomes in chronic heart failure: analysis from the SHIFT study. Clin Res Cardiol 2013;102:11-22.

26. McMurray JJ, Packer M, Desai AS, Gong J, Lefkowitz MP, Rizkala $\mathrm{AR}$, et al. Dual angiotensin receptor and neprilysin inhibition as an alternative to angiotensin-converting enzyme inhibition in patients with chronic systolic heart failure: rationale for and design of the Prospective comparison of ARNI with ACEI to Determine Impact on Global Mortality and morbidity in Heart Failure trial (PARADIGM-HF). Eur J Heart Fail 2013;15:1062-73.

27. Fonarow GC, Hernandez AF, Solomon SD, Yancy CW. Potential Mortality Reduction With Optimal Implementation of Angiotensin Receptor Neprilysin Inhibitor Therapy in Heart Failure. JAMA Cardiol 2016;1:714-7. 